\title{
Korelasi Kemampuan Bernalar dengan Kemampuan Menyimak Kritis Debat pada Siswa Kelas X
}

\author{
Firda Ariani ${ }^{1}$, Dawud ${ }^{1}$, Imam Agus Basuki ${ }^{1}$ \\ ${ }^{1}$ Pendidikan Bahasa Indonesia-Universitas Negeri Malang
}

\begin{tabular}{l}
\hline INFO ARTIKEL \\
\hline Riwayat Artikel: \\
Diterima: $30-11-2018$ \\
Disetujui: $18-02-2019$ \\
\hline
\end{tabular}

\section{Kata kunci:}

reasoning skill; critical listening skill; debate;

kemampuan bernalar: kemampuan menyimak kritis, debat

\begin{abstract}
ABSTRAK
Abstract: Before practicing to debate, a debater needs to have good critical listening skill to understand the content of the debate. By listening critically to the content of the debate, debater is expected to have the right point of view and also to think critically about other arguments. In critical listening of debate, listeners think actively from oral information in debate. The critical listeners must have a logical, reasonable, and not misguided way of thinking through a valid reasoning skill so that critical listening process can be done well. The result of this research shows there is a significant correlation between reasoning skill and critical listening of debate. If reasoning skill is high, critical listening skill of debate is high. If reasoning skill is low, critical listening skill of debate is low.

Abstrak: Sebelum berlatih berdebat, seorang pendebat harus memiliki keterampilan menyimak kritis yang baik untuk memahami isi debat. Dengan menyimak secara kritis isi debat, seorang yang berdebat diharapkan memiliki sudut pandang yang tepat dan juga berpikir kritis tentang argumen pihak lain. Dalam menyimak kritis debat, penyimak berpikir secara aktif dari informasi lisan dalam debat. Penyimak yang kritis harus memiliki cara berpikir logis, masuk akal, dan tidak sesat melalui kemampuan bernalar yang valid sehingga proses menyimak kritis debat dapat dilakukan dengan baik. Hasil penelitian ini menunjukkan terdapat korelasi positif yang signifikan antara kemampuan bernalar dengan kemampuan menyimak kritis debat. Jika kemampuan bernalar tinggi, kemampuan menyimak kritis debat tinggi. Jika kemampuan bernalar rendah, kemampuan menyimak kritis debat rendah.
\end{abstract}

\section{Alamat Korespondensi:}

Firda Ariani

Pendidikan Bahasa Indonesia

Universitas Negeri Malang

Jalan Semarang 5 Malang

E-mail: firdaariani1993@gmail.com

Menyimak melibatkan aktivitas mental. Aktivitas mental tersebut digunakan untuk menerima dan memahami informasi dari sumber bahasa lisan. Aktivitas mental pada menyimak dilakukan secara aktif dan sadar sehingga berbeda dari kegiatan mendengar yang bersifat tidak sengaja dan tidak aktif (Mudjianto \& Susanto, 2010). Berdasarkan pandangan tersebut, menyimak membutuhkan kegiatan berpikir secara aktif karena melibatkan aktivitas mental. Proses berpikir pada menyimak dilakukan untuk memahami kode-kode bahasa secara lisan. Jenis menyimak yang dapat dijadikan sebagai alternatif untuk meneliti kemampuan menyimak dan berpikir adalah kemampuan menyimak kritis. Hal ini dikarenakan kemampuan menyimak kritis merupakan contoh langsung korelasi kemampuan menyimak dengan kemampuan berpikir, khususnya kemampuan berpikir kritis. Kemampuan berpikir kritis melibatkan kemampuan bernalar yang baik. Oleh karena itu, perlu adanya kajian mengenai korelasi kemampuan bernalar dengan kemampuan menyimak kritis.

Pemahaman mengenai debat pada masa sekarang memang diperlukan. Hal ini dikarenakan banyaknya informasiinformasi lisan di media elektronik yang dapat menimbulkan perpecahan. Pro dan kontra yang terjadi di masyarakat merupakan bagian dari pembelajaran debat. Dengan menganalisis dan memahami informasi dengan sudut pandang berbeda di dalam debat, siswa diminta untuk menghargai pendapat orang lain. Oleh karena itu, untuk memahami dua sisi informasi pada debat (pro dan kontra), kemampuan bernalar juga dibutuhkan. Kajian debat sebagai materi pembelajaran tersendiri di mata pelajaran Bahasa Indonesia SMK belum banyak dilakukan. Sebelum praktik berdebat, siswa perlu memiliki keterampilan menyimak yang baik untuk memahami isi debat. Dengan memahami isi debat, siswa diharapkan dapat memiliki sudut pandang yang tepat dalam berdebat dan juga berpikir secara kritis mengenai debat yang disampaikan. Oleh karena itu, perlu adanya penelitian menyimak kritis debat. 


\section{METODE}

Penelitian berjudul Korelasi Kemampuan Bernalar dengan Kemampuan Menyimak Kritis Debat pada Siswa Kelas X menggunakan metode kuantitatif dengan teknik korelasi. Variabel bebas penelitian ini adalah kemampuan bernalar. Variabel terikat penelitian ini adalah kemampuan menyimak kritis debat. Hal ini dikarenakan kemampuan bernalar diharapkan menjadi salah satu faktor penentu dari keberhasilan kemampuan menyimak kritis debat.

Penelitian ini dilakukan di SMKN 4 Batam sehingga populasi penelitian ini adalah siswa kelas X SMKN 4 Batam tahun tahun pelajaran 2018/2019 yang masih aktif bersekolah. Jumlah populasi penelitian ini adalah 437 siswa. Sampel penelitian ini diambil dari siswa kelas X SMKN 4 Batam. Pengambilan sampel berdasarkan teknik acak berkelompok (Cluster Random Sampling), yaitu dengan mengundi nama kelas secara acak. Jumlah kelas yang diambil ada enam kelas sehingga jumlah sampel penelitian adalah 130 siswa. Jumlah sampel penelitian pada enam kelas tersebut adalah 30\% dari jumlah populasi penelitian, sesuai jumlah sampel yang dikemukakan oleh Arikunto (Arikunto, 2006), yaitu 20-25\% atau lebih dari jumlah populasi yang ada.

Teknik pengumpulan data penelitian ini adalah teknik tes. Tes kemampuan bernalar dan tes kemampuan menyimak kritis debat disusun sendiri oleh peneliti dalam bentuk tertulis. Data penelitian ini ada dua, yaitu skor kemampuan bernalar dan skor kemampuan menyimak kritis debat. Berdasarkan uji normalitas data, data penelitian skor kemampuan bernalar dan skor kemampuan menyimak kritis debat berdistribusi normal. Analisis korelasional yang digunakan adalah analisis korelasi Product Moment Pearson. Untuk mengetahui apakah hubungan antarvariabel signifikan atau tidak, digunakan nilai. Jika nilai $\mathrm{p}<0,05$, maka terdapat korelasi yang signifikan antarvariabel. Jika nilai $\mathrm{p}>0,05$, maka tidak terdapat korelasi yang signifikan antarvariabel.

\section{HASIL}

Dari analisis statistik yang dilakukan, diperoleh koefisien kolerasi antara kemampuan bernalar dengan kemampuan menyimak kritis debat adalah $0,312(\mathrm{p}=0,00)$. Berdasarkan hasil tersebut, dapat dinyatakan bahwa siswa sampel yang memperoleh skor tinggi dalam bernalar, memperoleh skor tinggi pula dalam menyimak kritis debat. Sebaliknya, siswa sampel yang memperoleh skor rendah dalam bernalar, memperoleh skor rendah pula dalam menyimak kritis debat. Berdasarkan hasil tersebut dapat disimpulkan ada korelasi positif yang signifikan antara kemampuan bernalar dengan kemampuan menyimak kritis debat siswa $(\mathrm{p}<0,05)$. Dengan demikian, hipotesis penelitian "terdapat korelasi positif yang signifikan antara kemampuan bernalar dengan kemampuan menyimak kritis debat pada siswa kelas X” diterima.

\section{PEMBAHASAN}

Hasil analisis korelasi antara kemampuan bernalar dengan kemampuan menyimak kritis debat pada siswa kelas $\mathrm{X}$ menunjukkan hubungan yang positif dan siginifikan. Apabila kemampuan bernalar siswa tinggi, maka kemampuan menyimak kritis debat siswa juga tinggi. Sebaliknya, Apabila kemampuan bernalar siswa rendah, maka kemampuan menyimak kritis debat siswa juga rendah. Hasil analisis ini didukung dengan berbagai teori dan hasil penelitian yang sudah ada.

\section{Korelasi Kemampuan Bernalar dengan Kemampuan Menyimak Kritis Debat Berdasarkan Teori}

Hasil analisis penelitian ini sesuai dengan teori yang dikemukakan oleh Freely \& Steinberg. Berpikir kritis merupakan kemampuan untuk menganalisis, mengkritik, dan mengemukakan gagasan, bernalar secara induktif dan deduktif, untuk mencapai kesimpulan yang faktual atau penuh pertimbangan yang ditarik dari pernyataan yang tidak ambigu dari suatu pengetahuan atau kepercayaan (Freely \& Steinberg, 2009). Kemampuan menyimak kritis adalah jenis kemampuan menyimak yang melibatkan berpikir kritis. Menyimak kritis debat dapat berarti kemampuan untuk menganalisis, mengkritik, dan mengemukakan gagasan, bernalar secara induktif dan deduktif, untuk mencapai kesimpulan yang faktual dari debat yang telah disimak. Jadi, kemampuan bernalar memang memiliki korelasi dengan kemampuan menyimak kritis debat karena kemampuan bernalar adalah bagian dari kegiatan menyimak kritis debat itu sendiri.

Konsep menyimak kritis tentunya tidak terlepas dari konsep berpikir kritis itu sendiri. Peter A. Facione secara lebih lengkap mengemukakan enam poin dalam berpikir kritis. Keenam poin tersebut adalah interpretasi, analisis, evaluasi, inferensi, eksplanasi, dan regulasi diri (Facione, 2013). Debat adalah pertentangan lisan yang dilakukan oleh dua orang, dua tim atau dua grup untuk mempertentangkan atau mendukung sesuatu dengan berbagai alasan (Fedrizzi \& Ellis, 2010). Berdasarkan kedua teori tersebut, Kemampuan menyimak kritis debat membutuhkan kemampuan berpikir kritis. Dalam kegiatan berpikir kritis ada kegiatan menganalisis dan menginferensi (menarik simpulan). Kegiatan menarik simpulan menjadi inti dalam kemampuan bernalar. Orang yang melakukan kegiatan berdebat harus menyimak kritis apa yang disampaikan pihak lain untuk menganalisis kebenaran dan kelogisan semua pernyataan yang disampaikan pihak lain sehingga ia dapat menentang/menyanggah dan mempertahankan argumennya. Semua kegiatan tersebut membutuhkan kemampuan bernalar yang baik. Kemampuan bernalar adalah kemampuan menarik simpulan, menemukan kebenaran, dan berpikir logis. Tujuan dari kemampuan bernalar adalah melakukan kegiatan berpikir yang tidak sesat. Dalam kegiatan menyimak kritis, siswa harus memiliki jalan pemikiran yang logis, masuk akal, dan tidak sesat melalui kemampuan bernalar yang baik agar kegiatan menyimak kritis dapat dilakukan dengan baik. 
Faktor yang memengaruhi keterampilan menyimak ada dua, yaitu faktor dari dalam dan dari luar diri penyimak. Faktor dari dalam diri menyimak berupa faktor fisik, kompetensi linguistik, pengetahuan tentang topik, dan faktor mental. Faktor mental terdiri atas kondisi kejiwaan, motivasi, dan sikap penyimak. Faktor dari luar diri terdiri atas lingkungan tempat kegiatan menyimak, media yang digunakan dalam menyimak, dan kualitas pembicara (Zahro \& Eliyanah, 2011). Teori ini dapat menjadi acuan faktor kemampuan bernalar dalam menyimak. Kemampuan bernalar adalah kemampuan menarik simpulan, menemukan kebenaran, dan berpikir logis. Jika dikaitkan dengan faktor pengaruh dalam menyimak, maka kemampuan bernalar berkaitan dengan kompetensi pemahaman penyimak sehingga kemampuan bernalar dapat menjadi bagian pada faktor internal dalam menyimak kritis debat.

\section{Korelasi Kemampuan Bernalar dengan Kemampuan Menyimak Kritis Debat}

Menyimak memiliki tujuan alamiah yaitu membentuk atau mengemukakan pertanyaan terhadap suatu masalah. Jawaban dari pertanyaan tersebut diperoleh dari kegiatan menyimak sehingga menyimak melibatkan bernalar tentang bentuk atau jawaban dari pertanyaan tersebut (Haroutunian-gordon, 2011). Dari segi analisis konteks khusus, pada pengajaran keterampilan menyimak, seorang guru sangat diperlukan. Peran guru dalam mengajarkan menyimak terkait dengan keterampilan penalaran pedagogis dan pengambilan keputusan. Seorang guru akan memilih jenis konten tertentu dan menyesuaikannya untuk masing-masing konteks pengajaran tertentu (De, 2009). Suatu pendekatan yang berorientasi pada proses untuk menyelidiki kemampuan menyimak bahasa kedua dapat memberikan wawasan yang bermanfaat ke dalam proses kognitif yang dilakukan oleh penyimak (Vandergrift, 2007). Kajian-kajian tersebut mengarahkan adanya kaitan antara bernalar dan menyimak. Menyimak sangat erat kaitannya dengan proses kognitif. Proses kognitif membutuhkan kemampuan bernalar. Hal ini mendukung hasil penelitian bahwa terdapat korelasi positif dan signifikan antara kemampuan bernalar dengan kemampuan menyimak kritis debat.

Penyimak tingkat lanjut dapat lebih memahami makna simakan daripada penyimak tingkat menengah. Oleh karena itu, pengajar Bahasa Inggris sebagai bahasa kedua atau bahasa asing hendaknya mendorong pelajar untuk berpartisipasi dalam teks menyimak dan membuat simpulan dari teks menyimak (Abdalhamid, 2012). Hasil penelitian tersebut sejalan dengan analisis korelasi antara kemampuan bernalar dengan kemampuan menyimak kritis debat, walaupun bahasa yang diteliti berbeda. Pada penelitian yang dilakukan, kemampuan bernalar yang digunakan adalah kemampuan bernalar secar produktif. Maksud dari kemampuan bernalar secara produktif adalah mengharuskan siswa untuk merumuskan simpulan atau menghindari proses perumusan simpulan yang salah. Jika kemampuan siswa untuk merumuskan simpulan rendah, maka hasil simakan kritis debat mereka juga rendah. Jika kemampuan siswa untuk merumuskan simpulan tinggi, maka hasil simakan kritis debat mereka juga tinggi. Hal ini dikarenakan perumusan simpulan diperlukan untuk memahami makna simakan.

Kemampuan menyimak antara ragam akademik dengan ragam sehari-hari mempunyai aspek yang berbeda. Kemampuan menyimak ragam akademik membutuhkan kemampuan kognitif yang lebih tinggi daripada kemampuan menyimak ragam sehari-hari karena menyimak pada ragam akademik difungsikan untuk memperoleh pengetahuan atau transfer ilmu (Marx, Heppt, \& Henschel, 2017). Berdasarkan hasil penelitian tersebut apabila dibandingkan dengan hasil penelitian ini memang ada korelasi antara kemampuan bernalar dengan kemampuan menyimak kritis debat. Menyimak kritis debat merupakan kemampuan menyimak ragam akademik karena hal-hal yang dipaparkan pada debat bersifat ilmiah atau berkaitan dengan ilmu tertentu. Kemampuan bernalar merupakan bagian dari kemampuan berpikir atau kognitif. Dalam menyimak kritis debat, dibutuhkan kemampuan kognitif dalam bentuk kemampuan bernalar agar siswa dapat menerima kajiankajian yang dibahas pada debat yang telah disimak.

Menyimak, mengingat, dan menulis dapat diintegrasikan dengan mengeksplorasi dictogloss yang berarti kombinasi keterampilan menyimak dengan menuliskan teks pendek apa yang diingat setelah menyimak. Ada tahap memahami dan memori. Pada tahap tersebut dibutuhkan kemampuan menghubungkan kata dengan fitur semantik sesuai dengan konteks, mengidentifikasi hubungan sintaksis, serta mengaktifkan pengetahuan (Prince, 2013). Apabila dikaitkan kembali dengan penelitian ini, kemampuan bernalar diperlukan dalam menyimak kritis debat. Dalam menyimak kritis debat, juga diharuskan untuk menghubungkan kata dengan fitur semantik sesuai dengan konteks, mengidentifikasi hubungan sintaksis, serta mengaktifkan pengetahuan agar isi debat dapat dipahami. Untuk melakukan semua itu, diperlukan kemampuan bernalar dalam bentuk perumusan simpulan secara tertulis. Rumusan simpulan tersebut sebagai latihan kemampuan berpikir untuk mengambil keputusan dalam memahami isi debat yang telah disimak. Kemampuan bernalar pada penelitian ini mengharuskan siswa untuk merumuskan simpulan dalam bentuk tulisan sehingga melibatkan kegiatan menulis. Menulis dapat diintegrasikan dalam kemampuan menyimak.

Pemerolehan fakta ilmiah adalah bagian dari literasi ilmu dan memerlukan pemikiran kritis yang rasional. Pengetahuan rasional menggunakan kegiatan bernalar yang tepat dengan bukti-bukti yang ada untuk mencapai suatu simpulan (Valdecasas \& Correas, 2010). Salah satu kegiatan menyimak kritis debat adalah menginterpretasi isi debat yang telah disimak dengan membedakan fakta dan opini. Apabila dikaitkan dengan penelitian ini, maka kemampuan bernalar memang dibutuhkan pada kemampuan menyimak kritis debat. Siswa harus bernalar dengan berpikir secara logis apakah suatu pernyataan merupakan fakta atau opini. Siswa harus berpikir mengenai bukti-bukti yang ada untuk memutuskan suatu simpulan bahwa pernyataan tersebut tergolong fakta. Jika kemampuan siswa dalam bernalar rendah, maka siswa sulit untuk menelaah buktibukti yang ada dalam menentukan suatu pernyataan tergolong fakta atau opini. 
Dalam kajian fungsi bernalar, interpretasi informasi yang dikomunikasikan melibatkan pengaktifan sebuah konteks yang diyakini sebelumnya dan mengintegrasikan informasi yang baru dengan informasi lama. Proses ini dapat menyebabkan ketidaklogisan antara informasi lama dengan informasi yang baru (Mercier \& Sperber, 2011). Kajian tersebut mengarahkan bahwa menginterpretasikan informasi dibutuhkan kemampuan bernalar. Menyimak kritis debat memiliki unsur menginterpretasikan debat yang telah disimak. Korelasi antara kemampuan bernalar dengan kemampuan menginterpretasikan debat yang telah disimak sesuai dengan kajian Mercier dan Sperber mengenai fungsi bernalar. Hal ini berarti kemampuan bernalar dan kemampuan menyimak kritis debat memiliki korelasi.

AEG (Argumentation and Evaluation Strategy) digunakan untuk menganalisis klaim dan argumen pendukung. Dalam memperoleh pemikiran kritis, guru dan siswa bekerja melalui AEG, mereka akan menyelesaikan sembilan langkah yang mereprentasikan strategi penalaran kognitif yang fleksibel untuk membimbing siswa dan guru ketika mereka mengevaluasi argumen yang dibuat untuk mendukung klaim. Salah satu tahapan dari sembilan langkah tersebut melibatkan analisis dan interpretasi data (Bulgren \& Ellis, 2015). Salah satu kegiatan menyimak kritis debat adalah menganalisis isi debat yang telah disimak. Strategi penalaran kognitif memang terwakilkan dalam menganalisis suatu argumen, maka perlu adanya kemampuan bernalar untuk menganalisis informasi debat. Strategi penalaran memang dibutuhkan untuk menganalisis berbagai ide pada mosi debat serta menganalis informasi pendukung argumen debat. Itulah mengapa kemampuan bernalar dapat berkorelasi positif dan signifikan dengan kemampuan menyimak kritis debat.

Inferensi berarti bernalar dengan keyakinan (Boghossian, 2014). Kajian ini mengarahkan bahwa menginferensi itu sendiri adalah kegiatan bernalar. Salah satu kegiatan menyimak kritis debat adalah menginferensi isi debat yang telah disimak. Dalam menginferensikan debat yang telah disimak siswa diharuskan untuk merumuskan simpulan. Itulah sebabnya terdapat korelasi positif yang signifikan antara kemampuan bernalar dengan menyimak kritis debat. Analisis dominan menunjukkan kelancaran dan bernalar adalah prediktor terkuat pada menyimak pemahaman siswa kelas 3. Bernalar menjadi prediktor terkuat pada menyimak pemahaman siswa kelas 7 dan 10 (Tighe, Spencer, \& Schatschneider, 2015). Dari hasil kajian tersebut sudah terlihat jelas, kemampuan bernalar berkorelasi dengan kemampuan menyimak pemahaman. Kajian tersebut sesuai dengan hasil penelitian yang dilakukan, walaupun jenis menyimak yang diteliti berbeda. Hal ini berarti kemampuan bernalar memang berkorelasi dengan kemampuan menyimak termasuk menyimak kritis.

\section{SIMPULAN}

Simpulan penelitian ini adalah terdapat korelasi positif yang signifikan antara kemampuan bernalar dengan kemampuan menyimak kritis debat siswa kelas X SMK Negeri 4 Batam. Hal ini menunjukkan apabila kemampuan bernalar siswa tinggi, maka kemampuan menyimak kritis debat siswa juga tinggi. Sebaliknya, apabila kemampuan bernalar siswa rendah, maka kemampuan menyimak kritis debat siswa juga rendah.

Berdasarkan hasil penelitian, dapat dipaparkan saran-saran kepada tiga pihak terkait. Ketiga pihak tersebut, yaitu guru Bahasa Indonesia di SMK, siswa SMK, dan peneliti lain. Bagi guru bahasa Indonesia di SMK, hendaknya lebih mendorong siswa untuk meningkatkan kemampuan bernalar dan kemampuan menyimak kritis debat. Bagi siswa SMK, sebaiknya harus lebih sering melatih diri untuk bernalar dan menyimak secara kritis. Siswa perlu melakukan latihan diri karena hal ini tidak hanya berguna bagi pembelajaran di sekolah, namun juga untuk pengambilan keputusan persoalan di kehidupan sehari-hari. Bagi peneliti lain, hendaknya dapat melaksanakan penelitian lanjutan yang berkaitan dengan kemampuan bernalar dan kemampuan menyimak kritis debat siswa SMK. Penelitian lain dapat berkaitan dengan peningkatan kemampuan bernalar siswa SMK. Selain itu, penelitian yang berkaitan dengan peningkatan kemampuan menyimak kritis debat siswa SMK juga perlu dilakukan.

\section{DAFTAR RUJUKAN}

Abdalhamid, F. (2012). Listening Comprehension Strategies of Arabic-Speaking ESL Learners. Colorado State University. Arikunto, S. (2006). Prosedur Penelitian Suatu Pendekatan Praktik. Jakarta: Rineka Cipta.

Boghossian, P. (2014). What is Inference? Philosophical Studies. https://doi.org/10.1007/s11098-012-9903-X

Bulgren, B. J., \& Ellis, J. (2015). The Argumentation and Evaluation Guide: Encouraging NGSS-based Critical Thinking. Science Scope, 78-85.

De, A. (2009). Listening as an Easy Skill: Analysis of a Particular Context. International Journal of English Linguistics, 9(2002), 29-41.

Facione, P. A. (2013). Critical Thinking: What It Is and Why It Counts. Insight Assesment. http://www.student.uwa.edu.au/_data/assets/pdf_file/0003/1922502/Critical-Thinking-What-it-is-and-why-it-counts.pdf

Fedrizzi, M., \& Ellis, R. (2010). Debate. Mason: South-Western Cengage Learning.

Haroutunian-Gordon, S. (2011). Plato's Philosophy of Listening. Educational Theory, 61(2), 125-139. DOI: 10.1111/j.17415446.2011.00395.X

Marx, A., Heppt, B., \& Henschel, S. (2017). Listening Comprehension of Academic And Everyday Language In First Language and Second Language Students. Applied Psycholinguistics, 38(3), 571-600. https://doi.org/10.1017/S0142716416000333

Mercier, H., \& Sperber, D. (2011). Why do Humans Reason? Arguments for an Argumentative Theory. Behavioral and Brian Sciences, 34(2), 57-74. https://doi.org/10.1017/S0140525X10000968 
Mudjianto., \& Susanto, G. (2010). Materi Pembelajaran Menyimak. Malang: A3 (Asih Asah Asuh).

Prince, P. (2013). Listening, Remembering, Writing: Exploring the Dictogloss Task. Language Teaching Research, 17(4), 486500. https://doi.org/10.1177/1362168813494123

Tighe, E. L., Spencer, M., \& Schatschneider, C. (2015). Investigating Predictors of Listening Comprehension in Third-, Seventh-, and Tenth-Grade Students: A Dominance Analysis Approach. Reading Psychology, 36(8), https://doi.org/10.1080/02702711.2014.963270

Valdecasas, A. G., \& Correas, A. M. (2010). Science Literacy and Natural History Museums. Journal of Biosciences, 35(4), 507-514. https://doi.org/10.1007/s12038-010-0057-8

Vandergrift, L. (2007). Recent Developments in Second and Foreign Language Listening Comprehension Research. Language Teaching, 40(31), 191-210. https://doi.org/10.107/S0261444807004338

Zahro, A., \& Eliyanah, E. (2011). Menyimak Beragam Wacana Lisan. Malang: Pustaka Kaiswaran. 